\title{
Breastfeeding duration not associated with average adiposity levels in 6-year-olds to 13-year-olds, but adequate breastfeeding may be associated with lower adiposity in the upper percentiles
}

\section{Garth Edward Kendall}

10.1136/eb-2012-100895

Faculty of Health Sciences, Curtin University, Perth, Western Australia, Australia

Correspondence to: Garth Edward Kendall Faculty of Health Sciences, Curtin University, GPO Box U1987, Perth, Western Australia 6845, Australia;

g.kendall@curtin.edu.au

Commentary on: Crume TL, Bahr TM, Mayer-Davis EJ, et al. Selective protection against extremes in childhood body size, abdominal fat deposition, and fat patterning in breastfed children. Arch Pediatr Adolesc Med 2012;166:437-43.

\section{Implications for practice and research}

- This study provides some evidence that adequate breastfeeding may protect against extremes in childhood body mass index (BMI) and adiposity.

- Further research is needed to explore the differences noted at the upper and lower percentiles of BMI and adiposity.

\section{Context}

This study addresses the relationship between breastfeeding in infancy and being overweight or obese in childhood. In some previous studies, it has been found that breastfed infants are less likely to become overweight or obese in later life, while in others, the opposite has been found. Other studies have found no difference in rates of overweight or obesity for breastfed and non-breastfed infants. According to the World Health Organisation, childhood obesity is one of the most serious public health challenges of the $21 \mathrm{st}$ century. ${ }^{1}$ The worldwide prevalence of childhood overweight and obesity has increased from $4.2 \%$ in 1990 to $6.7 \%$ in 2010 . The prevalence is expected to rise to $9.1 \%$ by $2020 .^{2}$

\section{Methods}

The participants were 442 children and adolescents aged 6-13 years born in the same hospital in Denver (USA). Almost half (48\%) of the children were white and the remainder were either Hispanic (43\%) or African American (9\%). Children's height and weight were measured using a stadiometer and electronic scale. Abdominal fat deposition and fat patterning were determined by MRI. Children's total energy intake was assessed using the Block Kids Food Questionnaire, while the level of physical activity was ascertained by a self-report 3-day recall questionnaire. Pubertal development was assessed by child self-report Tanner staging. Race/ethnicity was obtained by mothers' self-report, as were maternal level of education and total household income.

Mothers' prepregnancy weight was taken from hospital records and height was measured using a stadiometer. The mothers were asked about breastfeeding, formula feeding and the introduction of solid food and other beverages that had taken place during infancy. From this information a composite measure of breastfeeding duration and exclusivity was constructed. To estimate an overall breast milk dose in months, the sum of months of exclusive breastfeeding was added to the weighted months of mixed breast and formula feeding. Breast milk months were then categorised as low ( $<6$ months) or adequate ( $\geq 6$ months). Multiple regression was used to model the effect of breastfeeding (low vs adequate) on BMI and adiposity, controlling for the child and maternal factors listed above. Specifically, linear regression was used to estimate the mean difference in BMI and adiposity levels, and quantile regression was used to estimate the median differences and differences at the 5th, 15th, 30th, 40th, 50th, 60th, 70th, 85th and 95th percentiles of BMI and adiposity levels.

\section{Findings}

On average, children who received adequate breastfeeding had a lower BMI and level of adiposity than those who received low breastfeeding, but these results were not statistically significant. On the contrary, adequate breastfeeding was associated with statistically significant reductions in BMI and in some measures of adiposity for adolescents at the 85th and 95th percentiles. Furthermore, at the 30th percentile and below, adequate breastfeeding was associated with increased adolescent BMI, although the differences were not statistically significant. The authors concluded that the study provides evidence that breastfeeding reduces BMI and adiposity in children who are at the upper percentiles of adiposity and increases BMI and adiposity at lower percentiles.

\section{Commentary}

The study has a number of strengths and also has a number of limitations that have been acknowledged by the authors. The greatest strengths are the direct measures of adiposity and the ethnically diverse population. These strengths are offset by two serious limitations. The first limitation is that mothers were asked to recall their experience of breastfeeding after 6-13 years. It is likely that many mothers will have forgotten at least some details about breastfeeding 
duration and exclusivity. The second limitation is that the mothers who participated were more highly educated than those in the general population. This is of concern because it is a source of contention in breastfeeding research as to whether the positive effects found are due to the mothers' level of education and other sociodemographic factors rather than the constituents of breast milk compared with formula milk. ${ }^{3}$

Competing interests None.

\section{References}

1. World Health Organization. Global strategy on diet, physical activity \& health: childhood overweight and obesity. Geneva: World Health Organization; 2012. http://www.who.int/ dietphysicalactivity/childhood/en/

2. de Onis M, Blossner M, Borghi E. Global prevalence and trends of overweight and obesity among preschool children. Am J Clin Nutr 2010;92:1257-64.

3. Oddy WH, Robinson M, Kendall GE, et al. Breastfeeding and early child development: a prospective cohort study. Acta Paediatr 2011;100:992-9. 

may be associated with lower adiposity in the upper percentiles

\author{
Garth Edward Kendall
}

Evid Based Nurs 2013 16: 17-18 originally published online September 5,2012

doi: 10.1136/eb-2012-100895

Updated information and services can be found at:

http://ebn.bmj.com/content/16/1/17.full.html

\title{
These include:
}

References This article cites 3 articles, 1 of which can be accessed free at: http://ebn.bmj.com/content/16/1/17.full.html\#ref-list-1

Email alerting Receive free email alerts when new articles cite this article. Sign up in service the box at the top right corner of the online article.

$\begin{array}{ll}\text { Topic } & \text { Articles on similar topics can be found in the following collections } \\ \text { Collections } & \text { Child health (15 articles) } \\ \text { Health promotion (12 articles) } & \text { Health education ( } 280 \text { articles) } \\ \text { Obesity (nutrition) ( } 77 \text { articles) } & \text { Obesity (public health) (77 articles) } \\ & \text { Child health (382 articles) } \\ \text { Childhood nutrition (104 articles) } \\ \text { Infant nutrition (including breastfeeding) (60 articles) } \\ \text { Reproductive medicine (257 articles) } \\ \text { Adolescent health (75 articles) } \\ \text { Diet (190 articles) }\end{array}$

To request permissions go to:

http://group.bmj.com/group/rights-licensing/permissions

To order reprints go to:

http://journals.bmj.com/cgi/reprintform

To subscribe to BMJ go to:

http://group.bmj.com/subscribe/ 


\section{Notes}

To request permissions go to:

http://group.bmj.com/group/rights-licensing/permissions

To order reprints go to:

http://journals.bmj.com/cgi/reprintform

To subscribe to BMJ go to:

http://group.bmj.com/subscribe/ 